\title{
ПРИОРИТЕТЫ ФОРМИРОВАНИЯ И РАЗВИТИЯ ФИНАНСОВО-ПРАВОВОГО РЕЖИМА ВАЛЮТНЫХ ОПЕРАЦИЙ В РОССИЙСКОЙ ФЕДЕРАЦИИ
}

\author{
(c) 2020 Казанкова Татьяна Николаевна \\ кандидат педагогических наук, доцент кафедры публичного права \\ Самарский государственный экономический университет, Россия, Самара \\ Email: tatianaok78@yandex.ru \\ (c) 2020 Павлова Елизавета Сергеевна \\ магистрант 2 курса института права \\ Самарский государственный экономический университет, Россия, Самара \\ Email: missis.lizochka@yandex.ru
}

В статье рассматриваются основные приоритеты формирования и развития финансовоправового режима валютных операций в Российской Федерации, принятые и обсуждаемые меры, которые позволят расширить использование валюты РФ в международных расчетах, а также активизируют использование российского рубля нерезидентами.

Ключевые слова: валюта, валютный контроль, резиденты, нерезиденты, валютное регулирование, репатриация.

В настоящее время действующий финансовоправовой режим валютных операций не просто имеет недостатки, по сути, оно зачастую не отвечает современным реалиям ведения бизнеса. Этот факт признают как предприниматели, так и регуляторы. В связи с чем в последнее время идет активная работа по внесению изменений в валютное законодательство.

На данный момент законодателем установлена административная и уголовная ответственность за нарушения требований валютного контроля. В уголовном кодексе РФ предусмотрена одна статья, устанавливающая ответственность за валютные нарушения - ст. 193 УК РФ. Административная ответственность определена ст. 15.25 КоАП РФ. Основной мерой наказания за совершенные нарушения в сфере валютного контроля предусмотрен штраф.

В настоящее время идет активная работа по либерализации валютного контроля. Рассмотрим некоторые изменения валютного законодательства.

Вступившим в силу законом со 2 декабря 2019 г. [2] (за исключением положения, касающегося участников бюджетного процесса) законом внесены существенные изменения, имеющие преимущественно позитивный характер, в первую очередь для физических лиц, являющихся резидентами для целей валютного законодательства. В целом Закон продолжает общий тренд на либерализацию валютного регулирова- ния, о котором мы сообщали в нашем предшествующем обзоре. Далее проведем обзор нового пакета изменений.

1. Изменение по отмене требований о репатриации доходов в рублях

Одним из самых ожидаемых нововведений является отмена требования о репатриации доходов в рублях. Дело в том, что до введения этих изменений компании, получающие от иностранных контрагентов денежные средства по внешнеторговым сделкам, обязаны были в определенный законом срок обеспечить поступление этих средств на счета в российских банках. При этом не исполнение данной обязанности грозило компании крупными денежными штрафами.

C началом этого года нововведения будут охватывать некоторые сферы экономики, в том числе сферу IT-сервиса. Законодательством предусмотрена определенная схема, в соответствии с которой до 2024 года будут отменены правила о репатриации в отношении всей суммы внешнеторгового контракта.

При этом законодатель позволяет оставлять выручку, полученную по внешнеторговым сделкам в российской валюте за рубежом.

Тем не менее за резидентами РФ сохраняется обязанность по надлежащему исполнению или прекращению внешнеторговой сделки путем зачисления от иностранных контрагентов на свои банковские счета денежных средств, в соответствии с условиями договоров, при этом валют- 
ные агенты вправе запрашивать подтверждающую документацию по завершению сделки.

Таким образом, видна неоднозначность принятых нововведений.

2. Изменения в области командировочных расходов и Тах-free

Расходы резидентов, связанные со служебными командировками за рубеж, юридические лица-резиденты могут возмещать наличной иностранной валютой. Возвращать неизрасходованные суммы авансов в таких случаях резиденты могут также наличной иностранной валютой.

Кроме того, юридические лица-резиденты получили возможность осуществлять расчеты с физическими лицами-нерезидентами в наличной валюте РФ, без использования банковских счетов в уполномоченных банках в отношении компенсации сумм налога на добавленную стоимость при вывозе товаров за пределы таможенной территории ЕАЭС.

3. Изменения в освобождении от репатриации для обслуживания займов и кредитов: новая географическая привязка

Закон изменяет условие для освобождения резидентов-юридических лиц от обязанности по репатриации денежных средств в суммах, необходимых для обслуживания займов/кредитов по договорам с нерезидентами исключительно на счета в российских банках. Если ранее такое освобождение применялось, в частности, к займам/кредитам, выданным на срок свыше двух лет по договорам займа/кредита с нерезидентами, являвшимися резидентами стран-членов ОЭСР или ФАТФ, то в новой редакции Закона нерезидент должен быть резидентом:

- страны-члена Евразийского экономического союза (далее - «ЕАЭС») или

- страны, осуществляющей обмен информацией в соответствии с Многосторонним соглашением компетентных органов об автоматическом обмене финансовой информацией от 29 октября 2014 г. (далее - «Многостороннее соглашение»), или

- страны, имеющей с РФ иной международный договор, предусматривающий автоматический обмен финансовой информацией.

Список стран, активировавших автоматический обмен с Россией, ведется на сайте ОЭСР и соответствует спискам стран, установленным Приказом ФНС России от 30 мая 2018 г. № МMB-7-17/360@, действовавшим с 7 июня
2018 г. по 4 января 2019 г., и Приказом ФНС России от 4 декабря 2018 г. № MMB-7-17/784@, действующим с 5 января 2019 г. по настоящее время (далее - «Списки»). Оба Списка содержат такие популярные юрисдикции как Швейцария и Великобритания; в последний Список были добавлены Азербайджан, Багамы, Маршалловы острова, Монако, ОАЭ, Гонконг и другие государства и территории. Именно эти Списки налоговые органы, скорее всего, будут использовать в ходе проверки соблюдения Резидентами требований валютного законодательства по новым правилам.

А вот, например, США и Канады в списках нет, поэтому, несмотря на то, что США и Канада являются членами и ОЭСР, и ФАТФ, к обслуживанию займов/кредитов в этих странах вышеуказанная льгота неприменима.

4. Изменение в освобождении для резидентов от обязанности подавать отчеты о движении средств

С 1 января 2020 г. вступили в действие изменения в Федеральный закон «О валютном регулировании и валютном контроле» [2], предусматривавшие освобождение резидентов от предоставления отчета о движении средств в отношении счетов (вкладов) резидентов в банках за пределами РФ (далее - «зарубежные счета») при одновременном выполнении трех условий:

- зарубежный счет находится в банке в стране-члене ОЭСР или ФАТФ,

- страна, где находится этот банк, осуществляет обмен информацией в соответствии с Многосторонним соглашением или иным международным договором, предусматривающим автоматический обмен финансовой информацией,

- общая сумма денежных средств, зачисленных на зарубежный счет за отчетный год, не превышает 600000 рублей или ее эквивалент в иностранной валюте, либо остаток денежных средств на зарубежном счете, на который в отчетном году зачисления не производились, не превышает 600000 рублей или эквивалент в иностранной валюте.

Закон внес следующие поправки в вышеупомянутые изменения (тоже связанные с изменением географической привязки):

- с 1 января 2020 г. освобождение резидентов от предоставления отчета обусловлено выполнением двух условий:

- зарубежный счет находится в банке в 
стране-члене ЕАЭС (а не в стране-члене ОЭСР или ФАТФ) или в стране, которая осуществляет обмен информацией в соответствии с Многосторонним соглашением или иным международным договором, предусматривающим автоматический обмен финансовой информацией,

- общая сумма денежных средств не превышает вышеуказанные пороги;

- освобождение распространяется на правоотношения, возникшие с 1 января 2018 г.

5. Изменения в зачислениях на счета резидентов в банках за пределами РФ: обмен информацией вместо жестких рамок

Со 2 декабря 2019 г. возможность зачисления от нерезидентов денежных средств на зарубежные счета резидентов РФ (физических и юридических лиц) в определенных случаях (ч. 1 ст. 5.1. Закона о валютном регулировании) обусловлена нахождением банка в стране, являющейся членом ЕАЭС, или в стране, осуществляющей обмен информацией в соответствии с Многосторонним соглашением, или имеющей с РФ иной международный договор, предусматривающий автоматический обмен финансовой информацией. Ранее условием допустимости зачислений от нерезидентов было нахождение банка в стране, являющейся членом ОЭСР и/или ФАТФ.

Вышеупомянутые случаи зачисления денежных средств включают:

- получение кредитов и займов на срок более двух лет;

- получение дохода от сдачи в аренду (субаренду) расположенного за пределами РФ имущества;

- получение купонного и иных видов доходов по внешним ценным бумагам, предусмотренных Федеральным законом «О валютном регулировании и валютном контроле»;

- получение денежных средств в результате отчуждения внешних ценных бумаг в установленных случаях;

- получение денежных средств, выплачиваемых Резиденту в виде дохода, полученного от передачи денежных средств и (или) ценных бумаг в доверительное управление;

- получение денежных средств от продажи транспортного средства, находившегося в собственности Резидента за пределами РФ.

Действие данного изменения распространено на правоотношения, возникшие с 1 января 2018 г. Следует учесть, что изменение географической привязки не должно затронуть опера- ции Резидентов по получению от нерезидентов средств в случаях, указанных в ч. 5.1. ст. 12 Закона о валютном регулировании, на счета в банках на территории государств-членов ФАТФ и/ или ОЭСР, осуществленных до 2 декабря 2019 г., поскольку акты валютного законодательства РФ, устанавливающие новые обязанности для резидентов и нерезидентов или ухудшающие их положение, обратной силы не имеют.

С учетом поправок, внесенных Законом и вступивших в силу со 2 декабря 2019 г. [2], с 1 января 2020 г. вступят в действие изменения в Закон о валютном регулировании, предусматривающие снятие ограничений на зачисления от нерезидентов на Зарубежные счета Резидентов по любым основаниям (в дополнение к тем, которые поименованы в ч. 5.1. ст.12 Закона о валютном регулировании) [1] при выполнении одного из условий:

- зарубежный счет находится в банке в стране-члене ЕАЭС;

- зарубежный счет находится в банке в стране, которая осуществляет обмен информацией в соответствии с Многосторонним соглашением или иным международным договором, предусматривающим автоматический обмен финансовой информацией.

При этом снятие ограничений при выполнении условия в отношении страны, где находится зарубежный счет, распространено на правоотношения, возникшие с 1 января 2018 г. [2]

До принятия Закона снятие ограничений предполагалось в отношении валютных операций с нерезидентами через Зарубежные счета в странах-членах ОЭСР или ФАТФ, осуществляющих автоматический обмен информацией. Действующий в настоящее время Список стран, с которыми осуществляется автоматический обмен финансовой информацией, и списки странчленов ОЭСР или ФАТФ, не совпадают. Например, такие страны как Азербайджан, Андорра, Багамы, БВО, Болгария, Кипр, Лихтенштейн, Маршалловы острова, Монако, ОАЭ не являются членами ни ОЭСР, ни ФАТФ, но включены в действующий в настоящее время Список, что безусловно благоприятно для резидентов, имеющих зарубежные счета в банках в этих странах.

Как упомянуто выше, списки стран, с которыми осуществляется автоматический обмен финансовой информацией, содержат такие финансовые центры как Швейцария и Великобритания, но не включают, например, США и Кана- 
ду. Поэтому, несмотря на то, что США и Канада являются членами и ОЭСР, и ФАТФ, Резиденты, имеющие счета в банках в этих странах и проживающие в РФ более полугода, со 2 декабря 2019 г. лишены возможности получать на такие счета вышеупомянутые доходы, так как они квалифицируются как незаконные валютные операции.

Исходя из приведенного краткого анализа, можно сделать вывод о том, что внесенные изменения носят благоприятный характер для резидентов, чьи зарубежные счета находятся в банках, расположенных в ЕАЭС или странах, включенных в вышеупомянутые списки (с учетом времени их действия).

Для резидентов, чьи зарубежные счета находятся в банках, расположенных в иных странах, например, в США, Канаде, данные изменения серьезно ограничивают перечень разрешенных валютных операций через такие счета. В частности, признававшиеся ранее законными зачисления на счета в банках этих стран доходы (например, кредиты и займы на срок более двух лет, арендные доходы, купонные доходы и т.п.) со 2 декабря 2019 г. квалифицируются как незаконные валютные операции [2].

6. Новый специальный субъект ВЭД

Новая редакция Закона о валютном регулировании содержит уточнение, согласно которому к резидентам также относятся юридические лица, являющиеся профессиональными участниками внешнеэкономической деятельности, включенные в специальный перечень (кроме международных компаний).

Ранее в законодательстве понятие «профессиональный участник внешнеэкономической деятельности» не использовалось, однако в будущем статус профессионального участника ВЭД может стать одним из условий для применения более мягких мер административной ответственности.

На данный момент соответствующая нормативная база отсутствует, однако Правительством РФ уже ведется работа в данном направлении, в частности, разработан проект Постановления.

Из пояснительной записки к проекту Постановления следует, что данные изменения также направлены на либерализацию валютного регулирования в части смягчения административной ответственности за нарушения валютного законодательства в отношении лиц, которые включены в перечень профессиональных участников внешнеэкономической деятельности.
7. Дополнены требования о репатриации

В первую очередь возникает обязанность по уведомлению фискальных органов о действиях, связанных со счетами резидентов РФ за рубежом как в банковских, так и иных организациях финансового рынка. При этом определения данной организации применительно к организациям, действующим за рубежом в российском законодательстве нет, однако по аналогии с организациями финансового рынка, действующими на территории РФ, можно указать, что нововведения касаются взаимодействия резидентов РФ с различными видами инвестиционных компаний, такими как брокеры, дилеры, инвестиционные фонды, форекс-дилеры.

Со 2 декабря 2019 г. резиденты обязаны представлять информацию о сроках иного исполнения или прекращения обязательств по внешнеторговым договорам (контрактам) в случаях и способами, которые разрешены законодательством РФ.

Полагаем, что под такими случаями и способами следует рассматривать, прежде всего, предусмотренные ч. 2 ст. 19 Закона о валютном регулировании [1] исключения из общего правила о репатриации (например, при проведении зачета встречных требований по определенным видам обязательств).

Нововведения предписывают также сообщать о движении средств по таким счетам, при этом законодатель не указал, что подпадает под определение этих средств, и охватывает ли это уведомление только операции с денежными средствами.

Законодатель не дает пояснения и по необходимости подачи уведомления по уже открытым счетам в банках и иных организациях, тем самым предполагается, что по таким счетам у резидента существует обязанность в рамках уведомления о движении средств.

Законодатель изменяет список допустимых операций по счетам, которые могут совершаться в случаях, установленных ЦБ РФ. При этом пока пояснения по данному вопросу на законодательном уровне приняты не были, существует Проект указаний ЦБ РФ, где либерально установлено, что не существует ограничений по сумме, видам операций, а также по субъектам валютных операций. Однако, как следует поступить, необходимо выяснять в каждом конкретном случае.

В дополнении также следует рассмотреть 
широко обсуждаемое в последнее время послабление валютного законодательства, получившее поддержку в Государственной Думе. Депутаты приняли поправки к административному кодексу, смягчающие ответственность за валютные правонарушения.

В первую очередь, речь идёт о невозможности привлечения к уголовной ответственности за впервые совершенные правонарушения в части неисполнения обязанности по зачислению или репатриации валютной выручки, если нет уголовно наказуемых деяний. В соответствии с изменениями в статью 193 УК РФ уголовная ответственность станет возможной только в случае, если участник ВЭД ранее уже привлекался к административной ответственности за подобные нарушения.

Во-вторых, законодателем пересмотрены пороговые суммы крупного и особо крупного размера при неисполнении обязанности по возврату валютной выручки (репатриации). Крупным размером будут считаться суммы от 100 миллионов рублей, особо крупным - от 150 миллионов.
Данные суммы могут относиться как к однократной транзакции, так и быть результатом совершенных в течение года нескольких валютных операций. Более строгие уголовные нормы закрепляются как в отношении группы лиц, действующей по предварительному сговору, так и в отношении организованной группы лиц.

В-третьих, в перечень возможных мер административного наказания за нарушения в сфере валютного законодательства добавляется предупреждение для ч. 4, 4.1, 5 статьи 15.25 КоАП РФ.

Подобные поправки стали ответом на многочисленные просьбы о либерализации валютного регулирования со стороны бизнеса.

Таким образом, основным приоритетом формирования и развития финансовоправового режима валютных операций в РФ является либерализация валютного контроля в рамках дедолларизации российской экономики и расширения объемов несырьевого экспорта. Уже принятые и обсуждаемые меры позволяют расширить использование валюты РФ в международных расчетах, активизируют использование российского рубля нерезидентами.

\section{Библиографический список}

1. Закон РФ от 9 октября 1992 года № 3615-1 (в ред. от 29 июня 2004 г. N 58-ФЗ) «О валютном регулировании и валютном контроле» [Электронный ресурс] - Режим доступа: https://base.garant.ru/3974461/

2. Федеральный закон от 02.08.2019 N 265-ФЗ (ред. от 02.12.2019) «О внесении изменений в Федеральный закон «О валютном регулировании и валютном контроле» в части либерализации ограничений на совершение валютных операций резидентами с использованием счетов (вкладов), открытых в банках, расположенных за пределами территории Российской Федерации, и репатриации денежных средств» [Электронный ресурс] - Режим доступа: https://www.garant.ru/products/ipo/prime/doc/71702720/ 